\title{
OPEN
}

\section{Publisher Correction: Regulation of the Hepatitis B virus replication and gene expression by the multi- functional protein TARDBP}

\author{
Grace Naswa Makokha, Hiromi Abe-Chayama, Sajeda Chowdhury, C. Nelson Hayes, \\ Masataka Tsuge, Tadahiko Yoshima, Yuji Ishida, Yizhou Zhang, Takuro Uchida, Chise Tateno, \\ Rie Akiyama \& Kazuaki Chayama
}

Correction to: Scientific Reports https://doi.org/10.1038/s41598-019-44934-5, published online 11 June 2019

In the original version of this Article, Figure 5 was published with an incorrect version of panel $5 \mathrm{~b}$. This has now been corrected in the HTML and PDF versions of the Article.

\begin{abstract}
(c) (i) Open Access This article is licensed under a Creative Commons Attribution 4.0 International License, which permits use, sharing, adaptation, distribution and reproduction in any medium or format, as long as you give appropriate credit to the original author(s) and the source, provide a link to the Creative Commons license, and indicate if changes were made. The images or other third party material in this article are included in the article's Creative Commons license, unless indicated otherwise in a credit line to the material. If material is not included in the article's Creative Commons license and your intended use is not permitted by statutory regulation or exceeds the permitted use, you will need to obtain permission directly from the copyright holder. To view a copy of this license, visit http://creativecommons.org/licenses/by/4.0/.
\end{abstract}

(C) The Author(s) 2020 